\title{
Book Review: Reginald M.J. Oduor's Introduction to Ethics
}

\author{
Samson O. Gunga \\ Department of Educational Foundations \\ University of Nairobi, Kenya \\ gungasamson@googlemail.com
}

Thought and Practice: A Journal of the Philosophical Association of Kenya (PAK)

New Series, Vol.1 No.2, December 2009, pp.105-107

thoughtandpractice@gmail.com $\boldsymbol{O R}$ thoughtandpractice@uonbi.ac.ke

TITLE OF BOOK: Introduction to Ethics

AUTHOR: Reginald M.J. Oduor

Nairobi: Sophia Publications Ltd., 2009, 116 pages

COVER: Paperback

ISBN: 9966-7457-0-X

This book is a product of more than a decade of Oduor's experience in teaching ethics (moral philosophy) at the University of Nairobi. In the course of this introduction, the reader gets to see the techniques of philosophic reflection in action, as they are employed to scrutinise various pertinent moral questions.

Chapter 1 sets forth the main components of Oduor's approach. He presents morality as a tool for the promotion of social harmony. In this regard, he points out that since actions emanating from any individual or social institution affects other individuals and social institutions, there is need to regulate such action. In the author's view, moral philosophy proceeds from five assumptions about the human person, namely, that he/she is self-conscious (aware of his/her uniqueness), social (at his/her best when he/she interacts with fellow human beings), rational (able to provide grounds for his/her claims), creative (capable of coming up with new ways of performing old tasks), and moral (able to distinguish right action from wrong action, and virtuous 
character from vicious character). The author then introduces his readers to the four main approaches to the study of morality, namely, descriptive ethics (which is the province of the social sciences), normative ethics, meta-ethics and applied ethics.

In chapter 2, the author uses Socrates' response to his trial and execution to paint a picture of sound ethical reasoning, with a view to helping his readers to gain a deeper appreciation of the content and methodology of the three aspects of moral philosophy. Socrates refused to escape from unjust trial and execution because he was of the view that doing so would have been contrary to the dictates of morality through the violation of requirements such as loyalty and civic responsibility. The author argues that Socrates is an exemplar of deep commitment to ethical principles, in that he (Socrates) insisted on the need for sobriety, independent thinking and the necessity of upholding morality above prudence.

In the third chapter, Oduor introduces his readers to the nature and function of ethical theories. He then presents the two main normative ethical theories, namely, deontology and teleology. He also presents the views of the proponents of authoritarian accounts of morality, which are usually based on public opinion or divine commands, but points out that no further attention will be given to this viewpoint because it is not part of ethical theory proper.

Chapter 4 presents the deontology of Immanuel Kant, which emphasizes the need for universalisability of moral maxims, the intrinsic infinite worth of every human being, and the important place of freedom in morality. Chapter 5 examines three teleological ethical theories, namely, ethical egoism (which advocates maximisation of selfinterest), ethical universalism (which prescribes maximisation of advantage to the greatest number of people), and altruism (which champions the exclusive maximisation of the welfare of others).

Chapters 6 and 7 introduce the reader to meta-ethics - the exploration of the meaning of moral judgments and concepts, and the justification of moral judgments. The purpose of meta-ethics, the author tells us, is to attempt to answer the question of the possibility of achieving objectivity or intersubjectivity with regard to our understanding of moral judgements and concepts. Chapter 6 examines the meaning of 
moral judgments, with special reference to cognitivism (definism and intuitionism) and non-cognitivism (emotivism). It also briefly addresses the vibrant debate between ethical absolutists and ethical relativists, and helps the reader to view it in the light of the discussion presented so far (chapters 1-6). Chapter 7 examines some pairs of moral concepts, namely, freedom and responsibility, rights and duties, equality and justice, and conscience and conscientiousness.

The last chapter, the eighth, is a masterly summary of the discussion, and an appeal to the reader to pursue the study of ethics beyond the introductory presentation in the book.

All in all, Oduor's Introduction to Philosophy is of great relevance to both undergraduate and post-graduate students of "pure philosophy" and "philosophy of education". The author has gone out of his way to balance the unavoidable technical terminology of the discipline of philosophy with prosaic language that makes it easy to follow the discussion. The study questions at the end of each chapter are carefully designed to enhance the reader's own involvement in the penetrating reflection that the book is intended to introduce him/her to. 